adequate representation within the overall limit of eight lectures" (p.1). Similarly, the authors of Risk Watch fail to recognize that risk is only in a very limited sense a statistical concept. At its heart, risk is essentially a culturally learned response to uncertainty, a point made repeatedly by Mary Douglas and Aaron Wildavsky in Risk and Culture (University of California Press, 1982), a book that should be read in conjunction with the two under review. Hermann Bondi, then of the Natural Environment Research Council, in a perceptive introductory essay in Risk, captures the contradictions inherent in risk assessment by noting that people today want to be sure that "at the end of their day's work they can get away safely to go hang-gliding" (p.12).

Neither Urquhart and Heilmann nor the contributors to Risk seem to recognize that the identification and management of risks are political problems (the "politicizing of nature" is the term used by Douglas and Wildavsky). For example, although Risk Watch was first published in Munich, it makes only passing reference to the Greens, the West German political party that is the only successful environmental party in a major industrial nation. The programme of the Greens is based on the premise that large-scale technology and competitive capitalism are destroying the environmental foundations of human life; its assessment of the nature of risk is in sharp contrast to that of these authors.

Risk is a concept that varies in meaning from culture to culture. The authors of these two books largely ignore this. They also ignore the point that the importance placed upon risk and its determinants is a political fact of our time: witness, for example, the various interpretations of the recent tragedy at the Union Carbide plant in Bhopal. And they do not recognize that accidents cannot be adequately explained by the interaction between a flawed technology and statistical probability; on the contrary, accidents happen in large part because of flaws in the social system that controls the technology. This was the main conclusion of all the inquiries into the 1979 accident at the Three Mile Island nuclear power plant and was the theme of one of the scholarly byproducts of that accident, Charles Perrow's Normal Accidents (Basic Books, 1984), which I reviewed for Nature last year $(309,185 ; 1984)$.

Both books, then, give short shrift to the irfluence of culture, politics and social systeris or. risk and its perception. They are nonetheless important counterweights to journalistic sensationalism and useful introductions to the burgeoning field of risk-benefit analysis.

David L. Sills is Executive Associate at the Social Science Research Council, 605 Third Avenue. New York. New York 10158. USA. He is a co-editor of Accident at Three Mile Island (Westview. 1982) and The Three Milc Island Nuclear Accident (New' York Academ, of Sciences, 1981).

\section{Some information on recombination}

\author{
Harold L.K. Whitehouse
}

Genetic Recombination. Edited by John H. Wilson. Benjamin/Cummings: 1985. Pp.517. \$29.95, £29.95.

TEN articles from Annual Reviews of Genetics, four from Annual Reviews of Biochemistry and one from Annual Reviews of Plant Physiology make up this volume. The articles were originally published at various dates from 1975 to 1983 and are reprinted unchanged, but with new page numbers. All are concerned either directly or marginally with aspects of genetic recombination, and all of the authors have addresses in the United States or Canada.

The reviews are grouped under three headings: meiotic, mitotic and bacterial recombination. This division is somewhat arbitrary, as J.H. Wilson states in his preface to the book. Thus, the meiotic section includes F.W. Stahl's review of 1979, which is based primarily on the chi sites in bacteriophage $\lambda$ of Escherichia coli, and C.M. Radding's review of 1978 , which is concerned with molecular studies and so necessarily centres on work with prokaryotes. In the mitotic section there is an article by R.A. Weinberg on animal virus genome integration, and one by H.O. Smith and D.B. Danner on genetic transformation which, not surprisingly, is largely concerned with bacteria. The bacterial section is also misnamed as two of the reviews deal with bacteriophage recombination. A more serious criticism of this grouping is that it tends to obscure a central issue, namely, the need to see recombination phenomena as a whole. Many of the reviews are relevant to both prokaryotes and eukaryotes and, within the latter, to both meiotic and mitotic events. Putting the reviews into categories serves little purpose, though the helpful index does mitigate the problem to some extent. In a rapidly advancing field a chronological sequence might have been best.

One of the most useful papers in the book is a detailed survey by B.S. Baker $e t$ al. of what is known about the genetic control of meiosis in fungi, Drosophila and flowering plants, supported by nearly 700 references. There are also two valuable accounts of molecular studies on recombination, one by C.M. Radding and the other by D. Dressler and H. Potter. On the other hand, several of the reviews are concerned with topics that have contributed little to understanding the mechanisms of recombination, for example, sister chromatid exchange (reviewed by S.A. Latt); animal virus genome integration; and the molecular genetics of bacteriophage P1 (N. Sternberg and R. Hoess).
Although the publisher states on the cover that the volume represents the best overview available today, this is not to say that the reader will obtain a current picture of the subject. There is no review of transposable DNA and no discussion of the double-strand-break repair model of recombination proposed in 1983 by J.W. Szostak and associates. A postscript to bring the topic up to date would have improved some of the older reviews, for example Stahl's on specialized sites in recombination, that by P.J. Hastings on fungal recombination and that by T.R. Broker and A.H. Doermann on recombination in bacteriophage T4. Better than nothing would have been a list of references to important new work.

Harold L. K. Whitehouse is Emeritus Reader in Genetic Recombination in the Department of Botany, University of Cambridge, Downing Street, Cambridge CB2 3EA, UK.

\section{Talk of the town}

\section{Margaret C. Jacob}

William Whiston: Honest Newtonian. By James E. Force. Cambridge University Press: 1985. Pp.208. £25, $\$ 37.50$.

TRY TO conjure up a London coffee house of the early eighteenth century, where the genteel and the mercantile jostle with clergymen as well as fellows of the Royal Society; and then ask to listen in on their discourse. That, in effect, is what cultural historians with an interest in the reception of science in the time of Newton have been doing for the past 15 years or so. We have now succeeded, through a reading of the printed and manuscript sources of this period - when Newton's science and the recently published Principia (1687) were first discussed - to reconstruct in a plausible way what those gentlemen were saying (women did not frequently attend coffee houses but they did go to hear sermons).

James E. Force's book on William Whiston, Anglican clergyman, pulpit orator, coffee-house lecturer, is a fine contribution to that reconstruction and it comes with the added claim that Whiston, one of Newton's earliest and closest followers, more accurately and honestly (than other Newtonians) said what the master truly believed. For example, Newton and Whiston were anti-Trinitarians; only Whiston went out on the limb and much to the horror of his mentor said it publicly. As a result, he lost his professorship in Cambridge. In addition both were avid millennarians, that is, they believed in the end of historical time as foretold in the Bible, a destruction and consequent paradisiacal reconstruction to be accomplished by direct divine intervention. To put it simply, a modern thinker could hear totally unexpected discussions in those coffee houses and pulpits, indeed 